\title{
Supramolecular Potential of Vanadium $\beta$-Diketonate and Picolinate Compounds and The First One-dimensional Oxidovanadium(IV) Complex with $\beta$-Diketonate Ligand
}

\author{
Tanja Koleša-Dobravc, Anton Meden and Franc Perdih* \\ Faculty of Chemistry and Chemical Technology, University of Ljubljana, Večna pot 113, P. O. Box 537, SI-1000 Ljubljana, \\ Slovenia, and CO EN-FIST, Trg Osvobodilne fronte 13, SI-1000 Ljubljana, Slovenia \\ * Corresponding author: E-mail: franc.perdih@fkkt.uni-lj.si
}

Received: 22-09-2014

Dedicated to the memory of Prof. Dr. Jurij V. Brenčič

\begin{abstract}
Three vanadium compounds with $\beta$-diketonato or picolinato ligands were prepared and structurally characterized. In compounds $\left[\mathrm{VO}(\mathrm{tfpb})_{2}\right]_{\infty}(\mathbf{1})\left(\mathrm{tfpb}=4,4,4\right.$-trifluoro-1-phenylbutane-1,3-dionate) and $\left[\mathrm{VO}(\mathrm{acac})_{2}\right.$ (2-pyridone) $)$ (2) the coordination of vanadium atom is octahedral and in the compound $\mathrm{Hpy}\left[\mathrm{VO}_{2}(\mathrm{pic}) \mathrm{Cl}\right](\mathbf{3})$ the central atom is pentacoordinated. X-Ray crystallographic studies reveal infinite chain formation with the $\mathrm{V}=\mathrm{O} \cdots \mathrm{V}=\mathrm{O}$ interactions in $\mathbf{1}$, while $\mathbf{2}$ and $\mathbf{3}$ are mononuclear compounds. Centrosymmetric hydrogen-bonded dimers are formed in $\mathbf{2}$ via $\mathrm{N}-\mathrm{H} \cdots \mathrm{O}$ interactions due to the 2-pyridone ligand. In $\mathbf{3}$ the $\mathrm{Hpy}^{+}$cation is hydrogen bonded to the complex anion and crystal structure is further stabilized by $\pi \cdots \pi$ and $\mathrm{C}-\mathrm{H} \cdots \mathrm{O}$ interactions.
\end{abstract}

Keywords: $\beta$-Diketonates, Picolinates, Vanadium, Crystal structure, $\pi \cdots \pi$ interaction

\section{Introduction}

The coordination chemistry of vanadium complexes with various $\mathrm{N}$-, $\mathrm{O}$ - and $\mathrm{S}$-donor chelating ligands has received considerable attention due to their interesting properties and applications. Vanadium compounds, among them also $\beta$-diketonates and picolinates, are intensively studied for medical applications, they possess insulin enhancing activity, ${ }^{1}$ anticarcinogenic, antiproliferative, antiparasitic (Chagas disease) and other effects. ${ }^{2-4}$ The interactions of vanadium compounds with blood transport proteins have also been studied. ${ }^{5}$ Additionally, vanadium complexes are used as catalysts in oxidation reactions, ${ }^{6}$ ionic liquids ${ }^{7}$ and as precursors in metal-organic chemical vapor deposition. ${ }^{8}$ Since the discovery of MIL-26 and MIL-47 at the beginning of the last decade ${ }^{9}$ the field of vanadium metal-organic frameworks started to grow considerably. ${ }^{10}$ MOF materials can be constructed by covalent and/or non-covalent bonds. The acetylacetonato (acac) and picolinato (pic) ligands were selected in this research as prototypical ligands still widely studied for medical ap- plications and also enabling the study of weak interactions. We were interested in the formation of non-covalent forces in these systems such as classical hydrogen bonds as well as $\mathrm{C}-\mathrm{H} \cdots \mathrm{O} / \pi$ and $\pi \cdots \pi$ interactions since they have been demonstrated as important tools for assembling molecules in crystal lattices. ${ }^{11,12}$ Furthermore, the fluorinated $\beta$-diketonato ligand 4,4,4-trifluoro-1-phenylbutane-1,3dionate (tfpb) was selected since it is not symmetric and possesses the phenyl group enabling not only the formation of $\pi \cdots \pi$ and $\mathrm{C}-\mathrm{H} \cdots \pi$ interactions, but also $\mathrm{C}-\mathrm{H} \cdots \mathrm{F}$, $\mathrm{F} \cdots \mathrm{F}$ and $\mathrm{C}-\mathrm{F} \cdots \pi$ interactions ${ }^{13}$ and also because no crystal structures of $\mathrm{VO}^{2+}$ compounds with tfpb were reported so far. We were also interested if the use of fluorinated $\beta$-diketonates would facilitate the polymer formation via $\mathrm{V}=\mathrm{O} \cdots \mathrm{V}=\mathrm{O}$ interactions in oxidovanadium(IV) compounds, since the introduction of fluorine atom to the ligand enhances the acid character of the central metal atom and the increase of the coordination number can occur.

The molecular and crystal structures of $\left[\mathrm{VO}(\mathrm{tfpb})_{2}\right]_{\infty}$ (1), [VO(acac)(2-pyridone)] (2) and $\mathrm{Hpy}\left[\mathrm{VO}_{2}\right.$ (pic)Cl] (3) are presented and their geometries are discussed. This 
study provides an insight into the influence of different types of ligands on the crystal architecture, hydrogenbond formation and $\pi \cdots \pi$ interactions.

\section{Experimental}

\section{1. Materials and Characterization}

Reagents and chemicals were obtained as reagent grade from commercial sources and were used as purchased without any further purification. $\mathrm{VO}(\mathrm{acac})_{2}$ was prepared according to a literature procedure. ${ }^{14}$ Infrared (IR) spectra $\left(4000-600 \mathrm{~cm}^{-1}\right)$ of the samples were recorded using a Perkin-Elmer Spectrum 100, equipped with a Specac Golden Gate Diamond ATR as a solid sample support. Elemental $(\mathrm{C}, \mathrm{H}, \mathrm{N})$ analyses were obtained using a Perkin-Elmer 2400 Series II CHNS/O Elemental Analyzer.

\section{2. Synthesis}

Compound 1 (prepared by a modified procedure ${ }^{3 a}$ ): 4,4,4-trifluoro-1-phenylbutane-1,3-dione (432 mg, 2.00 $\mathrm{mmol})$ was dissolved in methanol $(2 \mathrm{~mL})$. After addition of $\mathrm{NaCH}_{3} \mathrm{COO} \cdot 3 \mathrm{H}_{2} \mathrm{O}(272 \mathrm{mg}, 2.00 \mathrm{mmol})$ in water $(2$ $\mathrm{mL}$ ), the mixture was stirred for $5 \mathrm{~min}$ and then added dropwise to the solution of $\mathrm{VOSO}_{4} \cdot 5 \mathrm{H}_{2} \mathrm{O}(253 \mathrm{mg}, 1.00$ $\mathrm{mmol})$ in water $(3 \mathrm{~mL})$. A light brown precipitate occur- red. The mixture was stirred at $70{ }^{\circ} \mathrm{C}$ for additional $5 \mathrm{~min}$. The precipitate was filtered off and dried. Yield: $380 \mathrm{mg}$, $76 \%$. Crystals suitable for X-ray analysis were obtained either from ethanol/toluene solution of the product or from organic layer obtained after extraction of reaction mixture with chloroform $(2 \times 4 \mathrm{~mL})$ and addition of toluene $(2 \mathrm{~mL})$. In both cases after a few days of slow evaporation of solvents yellow needles were grown from the solution. IR (ATR, $\mathrm{cm}^{-1}$ ): 1597s, 1572m, 1547w, 1538w, $1455 \mathrm{~m}, 1321 \mathrm{~m}, 1311 \mathrm{w}, 1293 \mathrm{~s}, 1255 \mathrm{~m}, 1181 \mathrm{~m}, 1139 \mathrm{~s}$, 1095w, 1076w, 946w, 888s, 807m, 768m, 722m, 692m, $656 \mathrm{~m}, 601 \mathrm{~m}$. CHN elemental analysis calculated for $\mathrm{C}_{20} \mathrm{~F}_{6} \mathrm{H}_{12} \mathrm{O}_{5} \mathrm{~V}(\%)$ : C 48.31, $\mathrm{H} 2.43$; found: $\mathrm{C} 48.24, \mathrm{H}$ 2.32 .

Compound 2: $\mathrm{VO}(\mathrm{acac})_{2}(66 \mathrm{mg}, 0.25 \mathrm{mmol})$ was dissolved in warm chloroform $(5 \mathrm{~mL})$ and 2-pyridone $(24$ $\mathrm{mg}, 0.25 \mathrm{mmol}$ ) was added. The reaction mixture was stirred for $10 \mathrm{~min}$ and then allowed to stand at room temperature. Green crystals suitable for X-ray analysis were obtained after slow evaporation of the solvent. Yield: 36 $\mathrm{mg}, 55 \%$. IR (ATR, $\mathrm{cm}^{-1}$ ): 3088w, 2918w, 1647m, $1571 \mathrm{~m}, 1520 \mathrm{~s}, 1429 \mathrm{~m}, 1383 \mathrm{~m}, 1363 \mathrm{~s}, 1279 \mathrm{~m}, 1241 \mathrm{~m}$, $1168 \mathrm{~m}, 1018 \mathrm{~m}, 972 \mathrm{~s}, 931 \mathrm{~m}, 787 \mathrm{~s}, 781 \mathrm{~m}, 768 \mathrm{~m}, 738 \mathrm{~m}$, $679 \mathrm{~m}, 606 \mathrm{~m}$.

Compound 3: Ammonium metavanadate $(59 \mathrm{mg}$, $0.50 \mathrm{mmol})$ was suspended in water $(3 \mathrm{~mL})$ and picolinic acid (62 mg, $0.50 \mathrm{mmol}$ ) was added. The mixture was stir-

Table 1. Crystallographic and refinement data for $\mathbf{1 a}, \mathbf{1 b}, \mathbf{2}$ and $\mathbf{3}$.

\begin{tabular}{|c|c|c|c|c|}
\hline Parameter & $\begin{array}{l}{\left[\mathrm{VO}(\mathrm{tfpb})_{2}\right]} \\
(1 \mathrm{a})\end{array}$ & $\begin{array}{l}{\left[\mathrm{VO}(\mathrm{tfpb})_{2}\right]} \\
(1 \mathrm{~b})\end{array}$ & $\begin{array}{l}{\left[\mathrm{VO}(\text { acac })_{2}(2 \text {-pyridone })\right]} \\
(2)\end{array}$ & $\begin{array}{l}\mathrm{Hpy}\left[\mathrm{VO}_{2}(\mathrm{pic}) \mathrm{Cl}\right] \\
(3)\end{array}$ \\
\hline$\overline{M_{\mathrm{r}}}$ & 497.24 & 497.24 & 360.25 & 320.60 \\
\hline$T(\mathrm{~K})$ & $150(2)$ & 293(2) & 293(2) & $293(2)$ \\
\hline Crystal system & Orthorhombic & Orthorhombic & Triclinic & Monoclinic \\
\hline Space group & $C c c 2$ & $C c c 2$ & $P-1$ & $P 2_{1} / c$ \\
\hline$a(\AA)$ & $16.4708(7)$ & $16.7507(10)$ & $7.5066(3)$ & $10.5709(3)$ \\
\hline$b(\AA)$ & $16.8106(8)$ & $16.8587(14)$ & $10.6366(6)$ & $9.9246(4)$ \\
\hline$c(\AA)$ & $7.5120(4)$ & $7.5561(6)$ & $10.7430(5)$ & $13.4691(4)$ \\
\hline$\alpha\left(^{\circ}\right)$ & 90.00 & 90.00 & $88.063(3)$ & 90.00 \\
\hline$\beta\left(^{\circ}\right)$ & 90.00 & 90.00 & $75.206(3)$ & $115.553(2)$ \\
\hline$\gamma\left({ }^{\circ}\right)$ & 90.00 & 90.00 & $85.574(3)$ & 90.00 \\
\hline Volume $\left(\AA^{3}\right)$ & $2079.95(17)$ & $2133.8(3)$ & $826.78(7)$ & $1274.85(7)$ \\
\hline$Z$ & 4 & 4 & 2 & 4 \\
\hline$D_{\text {calc }}\left(\mathrm{Mg} / \mathrm{m}^{3}\right)$ & 1.588 & 1.548 & 1.447 & 1.670 \\
\hline$\mu\left(\mathrm{mm}^{-1}\right)$ & 4.772 & 0.545 & 0.629 & 0.998 \\
\hline$F(000)$ & 996 & 996 & 374 & 648 \\
\hline Crystal size (mm) & $0.20 \times 0.02 \times 0.02$ & $0.25 \times 0.05 \times 0.05$ & $0.20 \times 0.10 \times 0.08$ & $0.20 \times 0.07 \times 0.05$ \\
\hline Reflections collected & 3131 & 5510 & 6608 & 5461 \\
\hline Reflections unique $\left(R_{\text {int }}\right)$ & $1576(0.0203)$ & $1929(0.0402)$ & $3673(0.0355)$ & $2893(0.0217)$ \\
\hline Parameters & 241 & 234 & 212 & 174 \\
\hline$R, w R_{2}[\mathrm{I}>2 \sigma(I)]^{\mathrm{a}}$ & $0.0393,0.1007$ & $0.0533,0.1139$ & $0.0472,0.1200$ & $0.0375,0.0937$ \\
\hline$R, w R_{2}(\text { all data })^{\mathrm{b}}$ & $0.0468,0.1087$ & $0.0808,0.1295$ & $0.0645,0.1340$ & $0.0552,0.1047$ \\
\hline $\mathrm{GOF}, S^{\mathrm{c}}$ & $1.059,1.091$ & $1.104,1.123$ & 1.077 & 1.042 \\
\hline $\operatorname{Max} / \min \Delta \rho\left(\mathrm{e} / \AA^{3}\right)$ & $0.180 /-0.199$ & $0.132 /-0.187$ & $0.308 /-0.366$ & $0.230 /-0.319$ \\
\hline
\end{tabular}

${ }^{\mathrm{a}} R=\sum|| F_{\mathrm{o}}|-| F_{\mathrm{c}}\left|/ \sum\right| F_{\mathrm{o}} \mid \cdot{ }^{\mathrm{b}} w R_{2}=\left\{\sum\left[w\left(F_{\mathrm{o}}{ }^{2}-F_{\mathrm{c}}{ }^{2}\right)^{2}\right] / \sum\left[w\left(F_{\mathrm{o}}{ }^{2}\right)^{2}\right]\right\}^{1 / 2} .{ }^{\mathrm{c}} S=\left\{\sum\left[\left(F_{\mathrm{o}}{ }^{2}-F_{\mathrm{c}}{ }^{2}\right)^{2}\right] /(n / p)\right\}^{1 / 2}$ where $n$ is the number of reflections and $p$ is the total number of parameters refined. 
red for one minute and then pyridine $(79 \mathrm{mg}, 1.00 \mathrm{mmol})$, concentrated hydrochloric acid $(0.5 \mathrm{~mL})$ and methanol $(5$ $\mathrm{mL}$ ) were added. Yellow solution was stirred for an additional hour at room temperature and then filtered. After few days of slow evaporation of solvents, green crystals concomitantly with a few colorless crystals of $\mathrm{NH}_{4} \mathrm{Cl}$ were grown from the solution. They were filtered, washed with water and methanol, and dried. Yield: $107 \mathrm{mg}, 67 \%$. IR (ATR, $\mathrm{cm}^{-1}$ ): 3080w, 3062w, 2813br, 1685s, 1637w, $1606 \mathrm{~m}, 1536 \mathrm{w}, 1485 \mathrm{~m}, 1447 \mathrm{w}, 1374 \mathrm{w}, 1340 \mathrm{~s}, 1289 \mathrm{~m}$, 1240w, 1202w, 1162m, 1049m, 946m, 924s, 908m, 857m, 754s, 740m, 709m, 676s, 650m, 607w.

\section{3. X-ray Crystallography}

Single crystal X-ray diffraction data were collected at room temperature with an Agilent Technologies SuperNova Dual diffractometer with an Atlas detector (1a, 1b) and a Nonius Kappa CCD diffractometer $(\mathbf{2}, \mathbf{3})$ using monochromated Mo- $K_{\alpha}$ radiation $(\lambda=0.71073 \AA)(\mathbf{1 a}, \mathbf{2}, \mathbf{3})$ or $\mathrm{Cu}-K_{\alpha}$ radiation $(\lambda=1.54184 \AA)(\mathbf{1 b})$. The data were processed using CrysAlis Pro ${ }^{15}(\mathbf{1 a}, \mathbf{1 b})$ or $\operatorname{DENZO}^{16}$ (2, 3). The structures were solved by direct methods implemented in $\operatorname{SHELXS}^{17}(\mathbf{1 b})$, SIR-97 ${ }^{18}(\mathbf{2}, \mathbf{3})$ and SIR$2004^{19}(\mathbf{1 a})$ and refined by a full-matrix least-squares procedure based on $F^{2}$ with SHELXL-97. ${ }^{17}$ All the nonhydrogen atoms were refined anisotropically. All $\mathrm{H}$ atoms were initially located in a difference Fourier maps and then treated as riding atoms in geometrically idealized positions. In 1a C4-C10 atoms were refined with FLAT restrain. $\mathrm{V}$ atom, $\mathrm{O}$ atoms and $\mathrm{C} 7-\mathrm{C} 10$ atoms of phenyl group are disordered over two positions in the ratio
0.57:0.43, and the $\mathrm{CF}_{3}$ group is disordered over two positions in the ratio 0.53:0.47. $\mathrm{C}-\mathrm{F}$ and $\mathrm{V}=\mathrm{O}$ bond distances were restrained by SADI instruction, and ISOR restraint was used in refinement of fluorine, O1A, and O1B atoms. In $\mathbf{1 b} \mathrm{V}$ atom, $\mathrm{O}$ atoms, $\mathrm{CF}_{3}$ group, and phenyl group are disordered over two positions in the same ratios as in 1a. The fluorine atoms were fitted into regular tetrahedron using SADI instruction for $\mathrm{C}-\mathrm{F}$ and $\mathrm{F}-\mathrm{F}$ distances. F1A and F1B were additionally refined using ISOR restrain. The crystallographic data are listed in Table 1. Due to severe disorder the structure was also solved in the monoclinic $P 2_{1} / c$ and in the orthorhombic $C c c m$ space group, however, no improvement regarding the disordered part was achieved. For comparison, at the completion of the refinement the $R$-factor for $1 \mathrm{a}(150 \mathrm{~K})$ was 0.0393 for $C c c 2$ and 0.0505 for $C c c m$.

\section{Results and Discussion}

\section{1. Literature Data and Possible Geometry for Bischelated $\mathrm{VO}^{2+}$ Complexes of $\beta$-Diketonates}

The crystallographic evidence reveals that bis(diketonate) complexes of oxidovanadium(IV) [VO(diketonate $)_{2}$ ] display a square-pyramidal geometry with two $\beta$-diketonates in the equatorial position and an oxido ligand in the axial position (Scheme 1) ${ }^{20}$ In the case of nonsymmetric $\beta$-diketonates cis $(\mathbf{A})^{21}$ and trans $(\mathbf{B})^{3 a, 22}$ isomers are possible. However, the central metal atom is in such cases coordinatively unsaturated. The completion of<smiles>[R]C1=CC([R])=C2OP(=O)(O1)OC([R])C=C2[R]</smiles>

A

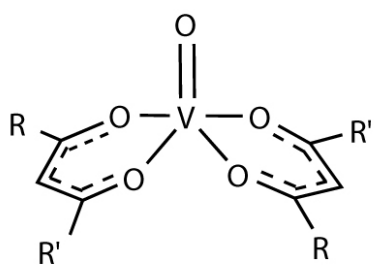

B<smiles></smiles>

C<smiles></smiles>

D

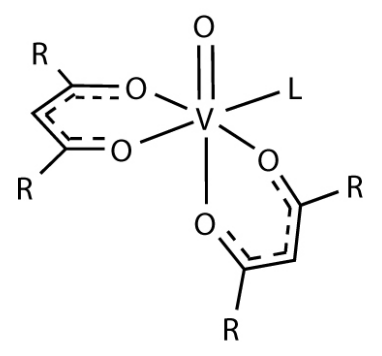

$\mathbf{E}$

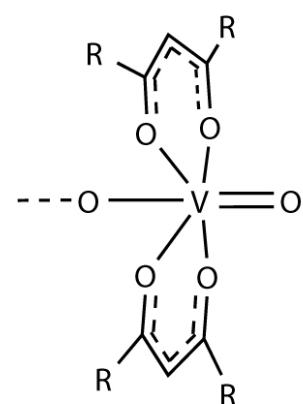

$\mathrm{R}$

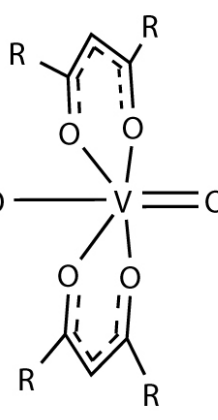

F

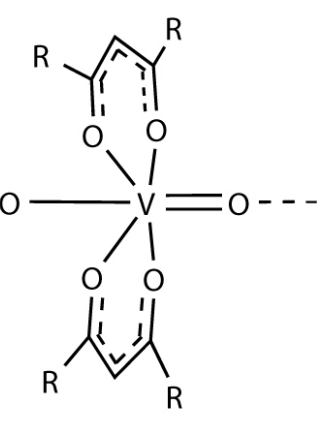

Scheme 1 
the coordination sphere can be achieved by adduct formation, in most cases by small neutral $\mathrm{O}$ - or $\mathrm{N}$-donating ligands, leading to $\left[\mathrm{VO}(\text { diketonate })_{2} \mathrm{~L}\right]$ species with ligand $\mathrm{L}$ in trans position to $\mathrm{VO}^{2+}$ moiety. ${ }^{23}$ In such octahedral species the non-symmetric $\beta$-diketonates bound to the central metal atom in equatorial position could still form cis $(\mathbf{C})^{3 \mathrm{a}}$ and trans isomers $(\mathbf{D})$. Additionally, the ligand L may lie not only in the axial position (trans to the $\mathrm{VO}^{2+}$ moiety), but also in equatorial position (cis to the $\mathrm{VO}^{2+}$ moiety) (E).$^{24}$ In none of these cases infinite structures are obtained, instead only discrete molecules are formed. In order to overcome this problem, we have to be aware that the supramolecular frameworks in the case of diketonates can be typically achieved using functionalized diketones or by the introduction of additional neutral ligands linking the metal centers thus enabling further connectivity. ${ }^{25} \mathrm{On}$ the other hand, in the case of oxidovanadium(IV) bis(diketonates) the third approach to form infinite covalently bound structures is possible due to $\mathrm{V}=\mathrm{O} \cdots \mathrm{V}=\mathrm{O}$ interactions $(\mathbf{F})$. The crystallographic evidence of such interaction is scarce, mostly polymeric oxidovanadium(IV) Schiff base compounds have been reported. ${ }^{26,27}$ In CSD no analogous polymeric crystal structures have been reported on $\beta$-diketonates. In the last decades it has been established that the introduction of fluorine atom into organic framework of the ligand enhances the acid character of the central metal atom and a stronger binding to the additional ligands can therefore occur. ${ }^{28}$ The increase in the coordination number from five to six can also be achieved as, for example, in the case of many copper $\beta$-diketonato complexes. ${ }^{28}$ It can be thus expected, that the enhanced acid character of vanadium center due to fluorinated $\beta$-diketonates could facilitate the polymer formation via $\mathrm{V}=\mathrm{O} \cdots \mathrm{V}=\mathrm{O}$ interactions.

\section{2. Synthesis and Characterization of Bis(4,4,4-trifluoro-1-phenylbutane-1,3- dionato)oxidovanadium(IV) (1a, 1b)}

Compound 1 was prepared from $\mathrm{VOSO}_{4} \cdot 5 \mathrm{H}_{2} \mathrm{O}$ and 4,4,4-trifluoro-1-phenylbutane-1,3-dione by a modified procedure published by Sgarbossa et al. ${ }^{3 a}$ Yellow needles of rather moderate quality but still suitable for X-ray analyses were obtained from ethanol/toluene or chloroform/toluene solutions at room temperature after a few days of standing on air. The IR spectrum of $\mathbf{1}$ fits well with the previously published ${ }^{3 a}$ with a strong band at 889 $\mathrm{cm}^{-1}$, which is according to the literature characteristic $\mathrm{V}=\mathrm{O}$ stretching band for polymeric $\cdots \mathrm{V}=\mathrm{O} \cdots \mathrm{V}=\mathrm{O} \cdots$ linear chain structures with distorted octahedral geometry. ${ }^{26}$

This observation is in accordance with results of the single crystal analysis. Two different crystals were analyzed by single crystal X-ray diffraction at $150 \mathrm{~K}$ (1a) and at room temperature (1b). Cell parameters at both temperatures are quite similar with the exception of axis $a$, that is elongated at higher temperature $(\sim 17 \%, 0.28 \AA$ A $)$. Crystal

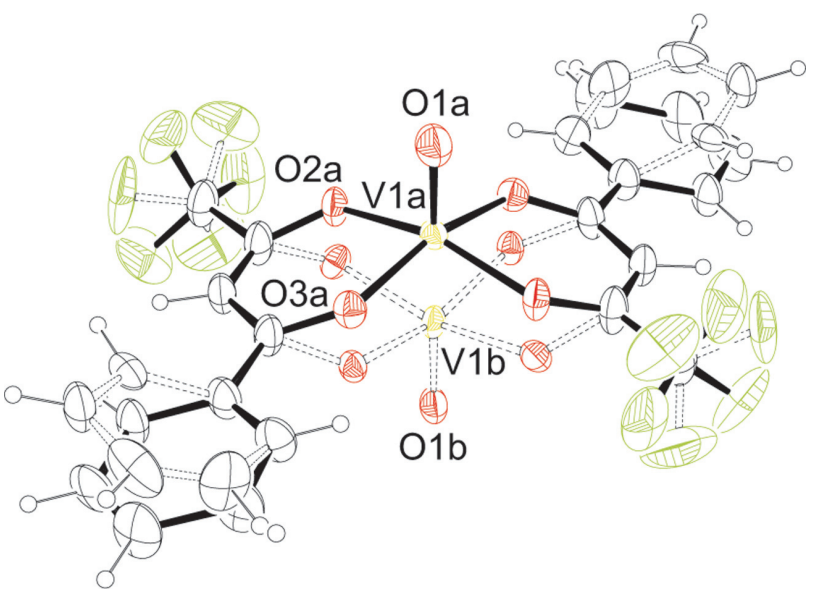

Figure 1. Structure of 1a with the atom-labeling scheme. Displacement ellipsoids are drawn at the $30 \%$ probability level. Disorder is presented by dashed lines.

structures were refined in orthorhombic $C c c 2$ space group and show the presence of one-dimensional polymeric structure.

Structures $\mathbf{1 a}$ and $\mathbf{1 b}$ are very similar. Selected bond distances and angles of 1a are summarized in Table 2, data of room temperature measurement $\mathbf{1 b}$ can be found in Supplementary material. Asymmetric unit of 1a contains one half of the bis(4,4,4-trifluoro-1-phenylbutane-1,3dionato)oxidovanadium(IV) complex with the $\mathrm{VO}^{2+}$ moiety on a twofold axis. Vanadium center has distorted octahedral geometry with carbonyl oxygen atoms of two bidentate tfpb ligands in the equatorial plane and with oxido atoms in axial positions (Figure 1). The first oxido atom is doubly bound to vanadium center, while the second is a part of the adjacent $\mathrm{VO}^{2+}$ moiety. Each oxido atom is therefore also a bridging atom to the next vanadium center enabling $\cdots \mathrm{V}=\mathrm{O} \cdots \mathrm{V}=\mathrm{O} \cdots$ interactions and causing the formation of one-dimensional coordination polymer.

The structure of 1a shows a great crystallographic disorder over two positions. The $\mathrm{VO}^{2+}$ moiety, carbonyl oxygen atoms and phenyl ring occupy two opposite positions with distinct refined occupation ratio of 0.57:0.43, while an easily rotatable $\mathrm{CF}_{3}$ group is disordered with the ratio $0.53: 0.47$. Both positions of the disordered complex give the same, only inverted, polymeric structure. To simplify, only the major part will be discussed briefly. Bond distance of $\mathrm{V}=\mathrm{O}$ double bond is $1.601(11) \AA$ and bond distance of $\mathrm{V} \cdots \mathrm{O}$ interaction is $2.155(11) \AA$. Vanadium is shifted $0.31 \AA$ out of the basal plane generated by the equatorial oxygen atoms. Tfpb ligand is bound to vanadium in a bidentate manner with the chelate angle $88.3(2)^{\circ}$ and $\mathrm{V}-\mathrm{O}$ bond distances $1.985(5)$ and 1.982(5) $\AA$. Angles between $\mathrm{O} 1$ and equatorial oxygen atoms are 99.3(2) and $98.5(2)^{\circ}$. Polymeric chain is stabilized by weak $\pi \cdots \pi$ stacking interactions with the centroid-tocentroid distance between phenyl rings of 4.215(8) $\AA$ (Figure 2). 
Table 2. Selected bond distances and angles for $\mathbf{1 a}$.

\begin{tabular}{|c|c|c|c|}
\hline$\overline{\text { Distance }}$ & (Å) & & \\
\hline V1A-O1A & $1.601(11)$ & V1B-O1B & $1.609(13)$ \\
\hline $\mathrm{V} 1 \mathrm{~A}-\mathrm{O} 2 \mathrm{~A}$ & $1.985(5)$ & V1B-O2B & $1.989(7)$ \\
\hline V1A-O3A & $1.982(5)$ & V1B-O3B & $1.990(6)$ \\
\hline V1A-O1A & $2.155(11)$ & V1B-O1B ${ }^{\text {iii }}$ & $2.147(13)$ \\
\hline Angle & $\left({ }^{\circ}\right)$ & & \\
\hline$\overline{\mathrm{O} 1 \mathrm{~A}-\mathrm{V} 1 \mathrm{~A}-\mathrm{O} 1 \mathrm{Ai}}$ & $180.000(4)$ & O1B-V1B-O1B ${ }^{\mathrm{iii}}$ & $180.000(2)$ \\
\hline O1A-V1A-O2A & $99.3(2)$ & O1B-V1B-O2B & $97.7(3)$ \\
\hline $\mathrm{O} 1 \mathrm{~A}-\mathrm{V} 1 \mathrm{~A}-\mathrm{O} 3 \mathrm{~A}$ & $98.5(2)$ & $\mathrm{O} 1 \mathrm{~B}-\mathrm{V} 1 \mathrm{~B}-\mathrm{O} 3 \mathrm{~B}$ & $99.0(3)$ \\
\hline $\mathrm{O} 2 \mathrm{~A}-\mathrm{V} 1 \mathrm{~A}-\mathrm{O} 2 \mathrm{~A}^{\mathrm{i}}$ & 161.4(5) & $\mathrm{O} 2 \mathrm{~B}-\mathrm{V} 1 \mathrm{~B}-\mathrm{O} 2 \mathrm{~B}^{\mathrm{i}}$ & $164.6(6)$ \\
\hline $\mathrm{O} 2 \mathrm{~A}-\mathrm{V} 1 \mathrm{~A}-\mathrm{O} 3 \mathrm{~A}$ & $88.3(2)$ & $\mathrm{O} 2 \mathrm{~B}-\mathrm{V} 1 \mathrm{~B}-\mathrm{O} 3 \mathrm{~B}$ & $89.7(3)$ \\
\hline $\mathrm{O} 2 \mathrm{~A}-\mathrm{V} 1 \mathrm{~A}-\mathrm{O} 3 \mathrm{~A}^{\mathrm{i}}$ & $88.9(2)$ & $\mathrm{O} 2 \mathrm{~B}-\mathrm{V} 1 \mathrm{~B}-\mathrm{O} 3 \mathrm{~B}^{\mathrm{i}}$ & $87.9(3)$ \\
\hline $\mathrm{O} 3 \mathrm{~A}-\mathrm{V} 1 \mathrm{~A}-\mathrm{O} 3 \mathrm{~A}^{\mathrm{i}}$ & $162.9(4)$ & $\mathrm{O} 3 \mathrm{~B}-\mathrm{V} 1 \mathrm{~B}-\mathrm{O} 3 \mathrm{~B}^{\mathrm{i}}$ & $162.1(5)$ \\
\hline $\mathrm{O} 1 \mathrm{~A}-\mathrm{ii}-\mathrm{V} 1 \mathrm{~A}-\mathrm{O} 2 \mathrm{~A}$ & $80.7(2)$ & O1B ${ }^{\mathrm{iii}}-\mathrm{V} 1 \mathrm{~B}-\mathrm{O} 2 \mathrm{~B}$ & $82.3(3)$ \\
\hline $\mathrm{O} 1 \mathrm{~A}^{\mathrm{ii}}-\mathrm{V} 1 \mathrm{~A}-\mathrm{O} 3 \mathrm{~A}$ & $81.5(2)$ & $\mathrm{O}^{\mathrm{B}} \mathrm{B}^{\mathrm{iii}}-\mathrm{V} 1 \mathrm{~B}-\mathrm{O} 3 \mathrm{~B}$ & $\mathrm{v} 81.0(3)$ \\
\hline
\end{tabular}

Symmetry codes: (i) $-x,-y, z$; (ii) $-x, y, z-1 / 2$; (iii) $-x, y, z+1 / 2$.

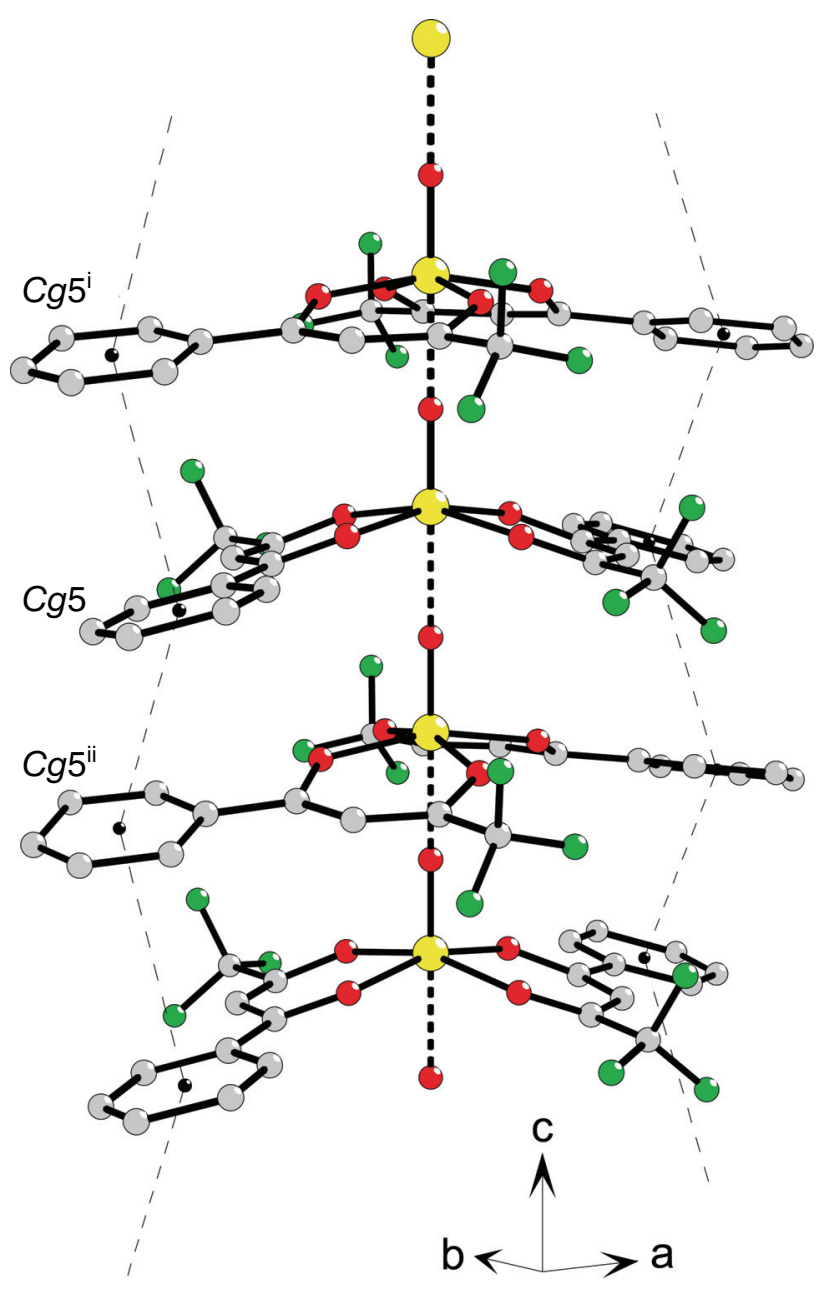

Figure 2. Coordination polymer of 1a. For clarity only one orientation of the coordination polymer chain without a minor part of the disorder is presented. Stabilization by $\pi \cdots \pi$ stacking interactions is indicated by dashed lines (symmetry codes: (i) $x,-y, z+1 / 2$; (ii) $x$, $-y, z-1 / 2)$

\section{3. Synthesis and Characterization of Bis(acetylacetonato)(2-pyridone) oxidovanadium(IV) (2)}

Compound 2 was prepared by mixing $\mathrm{VO}(\mathrm{acac})_{2}$ with 2-pyridone in 1:1 ratio in warm chloroform and crystals suitable for X-ray analysis were obtained by slow evaporation of the solvent at room temperature. In IR spectrum of $\mathbf{2}$ a stretching vibration of the $\mathrm{VO}^{2+}$ moiety is observed as a strong band at $972 \mathrm{~cm}^{-1}$. A band at 1635 $\mathrm{cm}^{-1}$ in the free 2-pyridone corresponding to $\mathrm{C}=\mathrm{O}$ vibration is shifted to $1647 \mathrm{~cm}^{-1}$ upon coordination. This vibration confirms the presence of the lactam form of 2-pyridone in compound 2 . Vibrations near $2918 \mathrm{~cm}^{-1}$ suggest the involvement of the $\mathrm{O}-\mathrm{H}$ group in the hydrogen bonding.

Compound 2 crystallizes as green prisms in the triclinic $P-1$ space group. Selected bond distances and

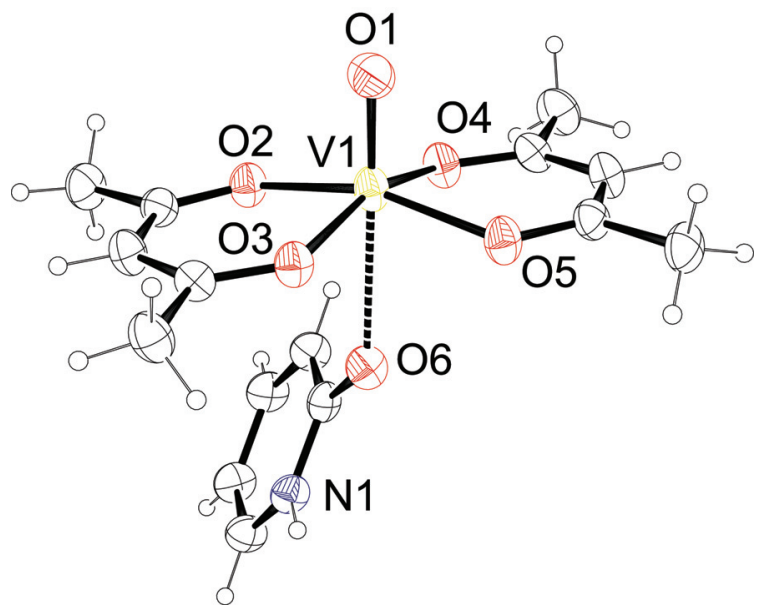

Figure 3. The asymmetric unit of $\mathbf{2}$ showing the atom-labeling scheme. Displacement ellipsoids are drawn at the $30 \%$ probability level. 
Table 3. Selected bond distances and angles for $\mathbf{2}$.

\begin{tabular}{llll}
\hline Distance & $(\AA)$ & & \\
\hline V1-O1 & $1.588(2)$ & V1-O4 & $1.9828(18)$ \\
V1-O2 & $1.9830(17)$ & V1-O5 & $1.9886(17)$ \\
V1-O3 & $1.9891(17)$ & V1-O6 & $2.515(2)$ \\
\hline Angle & $\left(^{\circ}\right)$ & & \\
\hline O1-V1-O2 & $100.14(10)$ & O2-V1-O5 & $160.66(8)$ \\
O1-V1-O3 & $99.74(10)$ & O3-V1-O4 & $160.09(8)$ \\
O1-V1-O4 & $100.16(10)$ & O3-V1-O5 & $88.56(7)$ \\
O1-V1-O5 & $99.18(10)$ & O4-V1-O5 & $88.84(7)$ \\
O2-V1-O3 & $88.86(7)$ & O1-V1-O6 & $174.65(9)$ \\
O2-V1-O4 & $87.10(7)$ & & \\
\hline
\end{tabular}

angles of $\mathbf{2}$ are summarized in Table 3. The vanadium atom in compound $\mathbf{2}$ is octahedrally coordinated (Fig. 3) with four oxygen atoms of two chelating acac ligands with V-O distances 1.983-1.989 $\AA$ in a basal plane and the vanadium atom lying $0.34 \AA$ above this plane. Bite angles $\mathrm{O}-\mathrm{V}-\mathrm{O}$ are $\sim 88.8^{\circ}$, while $\mathrm{O}-\mathrm{V}-\mathrm{O}$ in trans posi-

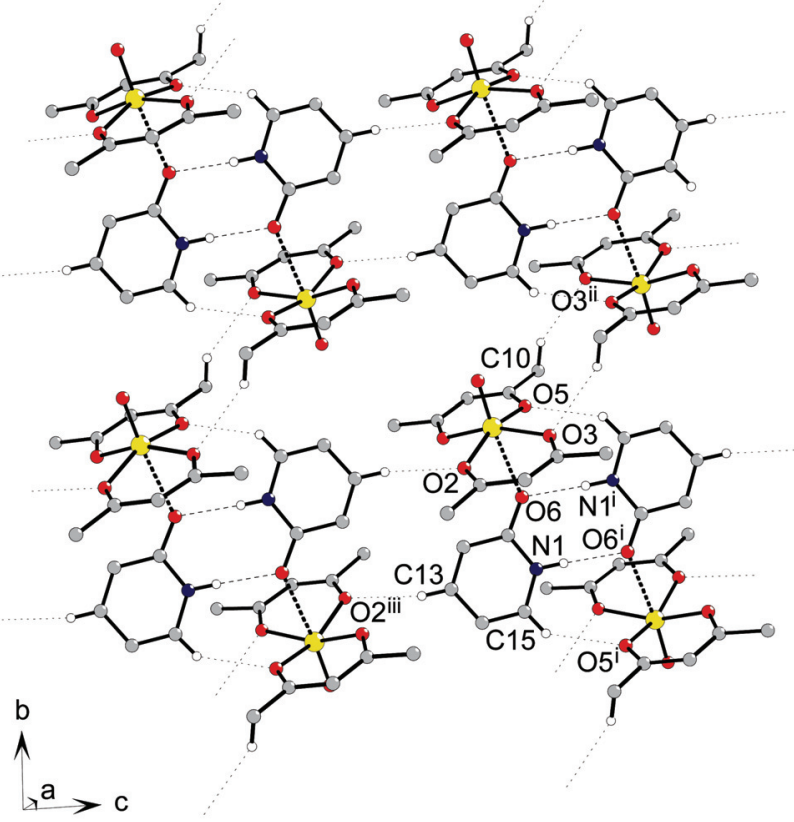

Figure 4. The 2D network parallel to the $b c$ plane in $\mathbf{2}$ formed by weak $\mathrm{C}-\mathrm{H} \cdots \mathrm{O}$ interactions (symmetry codes: (i) $-x+1,-y+1,-z$ +1 ; (ii) $-x+1,-y+2,-z+1$; (iii) $-x+1,-y+1,-z$ ). tions are $\sim 160^{\circ}$. The $\mathrm{V}=\mathrm{O}$ double bond length is $1.588(2) \AA$ and the $\mathrm{V}-\mathrm{O}$ (pyridone) is $2.515(2) \AA$. This distance is rather long; however, similar contacts in the range from 2.46 even up to $2.58 \AA$ were found in $\mathrm{CSD}^{29}$

Even though the carbonyl oxygen of the 2-pyridone ligand is coordinated to the vanadium center, it can still act as a hydrogen bond acceptor facilitating the formation of centrosymmetric hydrogen-bonded dimers via $\mathrm{N} 1-\mathrm{H} 1 \cdots \mathrm{O} 6(-x+1,-y+1,-z+1)$ interactions (Fig. 4, Table 4). Hydrogen-bonded dimers are further stabilized by weak $\mathrm{C} 15-\mathrm{H} 15 \cdots \mathrm{O} 5(-x+1,-y+1,-z+1)$ interactions and 2D framework is achieved by weak C13$\mathrm{H} 13 \cdots \mathrm{O} 2(-x+1,-y+1,-z)$ and $\mathrm{C} 10-\mathrm{H} 10 \mathrm{~A} \cdots \mathrm{O} 3(-x+1$, $-y+2,-z+1)$ interactions (Fig. 4).

\section{4. Literature Data and Structures for $\mathrm{VO}^{2+}$ Complexes of Monochelated Picolinates and Chlorido Compounds}

The crystallographic evidence on bischelated picolinato complexes of $\mathrm{VO}^{2+}$ has been discussed earlier. ${ }^{5 \mathrm{a}, 30}$ When examining the known monopicolinate complexes of dioxidovanadium $(\mathrm{V}), \mathrm{VO}_{2}$ (picolinate), we found only four structures and all display a trigonal bipyramidal geometry with a chelating picolinato or quinoline-2-carboxylato ligand and an additional monodentate ligand. ${ }^{31}$ Structures with chlorido ligand bonded to $\mathrm{VO}_{2}^{+}$are also not numerous, as only five entries in $\mathrm{CSD}$ could be found. All of these compounds were prepared under the inert atmosphere since $\mathrm{V}-\mathrm{Cl}$ bond can be easily hydrolyzed. Compounds $\left[\mathrm{VO}_{2} \mathrm{Cl}(\mathrm{py})_{2}\right]^{32,33}$ and $\left[\mathrm{VO}_{2} \mathrm{Cl}(\mathrm{O}-\mathrm{py})_{2}\right]^{33}$ possess trigonal bipiramidal and $\mathrm{PPh}_{3} \mathrm{Me}\left[\mathrm{VO}_{2} \mathrm{Cl}_{2}\right]^{34}$ tetrahedral geometry.

\section{5. Synthesis and Characterization of Pyridinium Chlorido(pyridin-2- carboxylato- $N, O)$ dioxidovanadate $(\mathrm{V})(3)$}

Compound 3 was prepared from ammonium metavanadate and picolinic acid with the addition of pyridine and hydrochloric acid. Small cubic crystals of a side product $\mathrm{NH}_{4} \mathrm{Cl}$ with similar solubility were present despite many attempts of washing and recrystallization of the compound 3. Anyway, we managed to isolate some single crystals suitable for X-ray analysis. In IR spectrum of $\mathbf{3}$ bands for aromatic $\mathrm{C}-\mathrm{H}$ vibrations are present at 3080 and $3062 \mathrm{~cm}^{-1}$,

Table 4. Hydrogen bonds for $2\left[\AA\right.$ and $\left.^{\circ}\right]$

\begin{tabular}{llllll}
\hline $\mathbf{D}-\mathbf{H} \cdots \mathbf{A}$ & $\mathbf{d}(\mathbf{D}-\mathbf{H})$ & $\mathbf{d}(\mathbf{H} \cdots \mathbf{A})$ & $\mathbf{d}(\mathbf{D} \cdots \mathbf{A})$ & $<(\mathbf{D H A})$ & $\begin{array}{l}\text { Symmetry transformation } \\
\text { for acceptors }\end{array}$ \\
\hline $\mathrm{N} 1-\mathrm{H} 1 \cdots \mathrm{O} 6$ & 0.86 & 2.02 & $2.884(2)$ & 177 & $-x+1,-y+1,-z+1$ \\
& & & & & \\
$\mathrm{C} 10-\mathrm{H} 10 \mathrm{~A} \cdots \mathrm{O} 3$ & 0.96 & 2.57 & $3.367(4)$ & 140 & $-x+1,-y+2,-z+1$ \\
$\mathrm{C} 13-\mathrm{H} 13 \cdots \mathrm{O} 2$ & 0.93 & 2.55 & $3.426(4)$ & 158 & $-x+1,-y+1,-z$ \\
$\mathrm{C} 15-\mathrm{H} 15 \cdots \mathrm{O} 5$ & 0.93 & 2.46 & $3.249(4)$ & 142 & $-x+1,-y+1,-z+1$ \\
\hline
\end{tabular}


as well as asymmetric and symmetric vibrations of $\mathrm{COO}^{-}$ group at 1685 and $1340 \mathrm{~cm}^{-1}$. The difference between asymmetric and symmetric stretching vibrations $\left(\Delta=v_{a \mathrm{~s}}-\right.$ $v_{\mathrm{s}}$ ) of $345 \mathrm{~cm}^{-1}$ is in accordance with the monodentate coordination of the $\mathrm{COO}^{-}$group to the $\mathrm{VO}_{2}^{+}$moiety. Stretching vibrations of the $\mathrm{VO}_{2}^{+}$group are observed as a medium band at $946 \mathrm{~cm}^{-1}$ and a strong band at $924 \mathrm{~cm}^{-1}$.

Compound $\mathbf{3}$ crystallizes as green prisms in the monoclinic $P 2 / c$ space group. Selected bond distances and angles of $\mathbf{3}$ are summarized in Table 5. Asymmetric unit of 3 consists of vanadium(V) complex anion and pyridinium cation as its counter ion (Fig. 5). Vanadium(V) metal center is pentacoordinated. The distortion of a trigonal bipyramid can be best described by the structural parameter $\tau$ ( 0 for an ideal square pyramid and 1 for an ideal trigonal bipyramid), ${ }^{35}$ which in this case has the value of 0.44 . This value would imply the presence of distorted square pyramid geometry; however, visual inspection would suggest distorted trigonal bipyramidal geometry. Although the trigonality index $\tau$ is a well established structural parameter some of the reported examples show that $\tau$ is not always a reliable guidance. ${ }^{36}$ This seems to be the case for compounds in which one metal-ligand bond is elongated, ${ }^{36}$ as is the case in $\mathbf{3}$. Reason for this is that the parame-

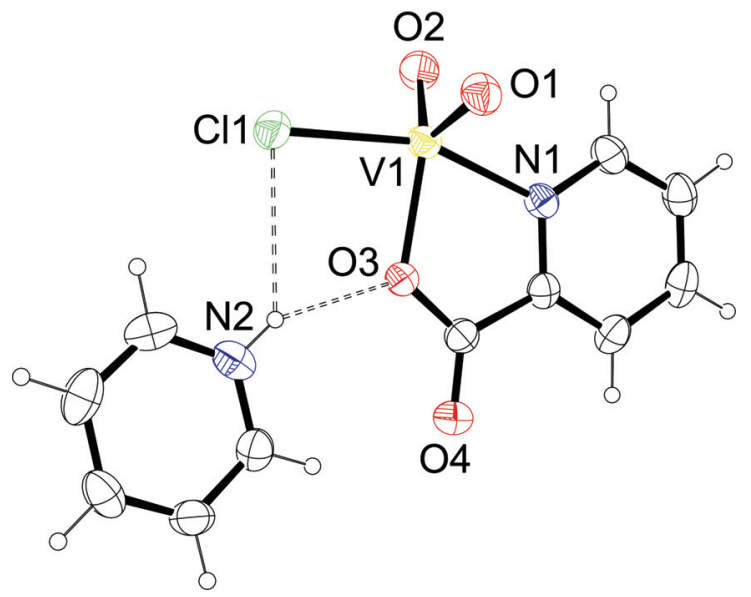

Figure 5. The asymmetric unit of $\mathbf{3}$ with atom labels. Ellipsoids are drawn at the $30 \%$ probability level. Dashed lines indicate hydrogen bonds.
Table 5. Selected bond distances and angles for $\mathbf{3}$.

\begin{tabular}{llll}
\hline Distance & $(\AA)$ & & \\
\hline V1-O1 & $1.6124(18)$ & V1-N1 & $2.125(2)$ \\
V1-O2 & $1.6276(18)$ & V1-Cl1 & $2.3308(8)$ \\
V1-O3 & $2.0347(15)$ & & \\
\hline Angle & $\left(^{\circ}\right)$ & & \\
\hline O1-V1-O2 & $108.41(10)$ & O3-V1-N1 & $75.17(7)$ \\
O1-V1-O3 & $117.23(9)$ & O1-V1-Cl1 & $100.32(7)$ \\
O2-V1-O3 & $132.76(9)$ & O2-V1-Cl1 & $99.37(7)$ \\
O1-V1-N1 & $93.36(9)$ & O3-V1-Cl1 & $84.42(5)$ \\
O2-V1-N1 & $91.19(9)$ & N1-V1-Cl1 & $159.03(6)$ \\
\hline
\end{tabular}

ter $\tau$ is based solely on the two largest $\mathrm{X}-\mathrm{M}-\mathrm{X}$ angles, and does not account for the distortion of the geometry due to bond elongations.

Pyridin-2-carboxylato (picolinato) ligand is bound to vanadium in a bidentate manner through nitrogen and carboxylato oxygen atoms with the chelate angle $75.17(7)^{\circ}$. The angle between $\mathrm{N} 1$ and $\mathrm{Cl} 1$ atoms is $159.03(6)^{\circ}$, angles between oxygen atoms are 108.41(10)-132.76(9) ${ }^{\circ}$, while angles between $\mathrm{N} 1$ or $\mathrm{Cl} 1$ and oxygen atoms are 84.42(5)-100.32(7) ${ }^{\circ}$. The $\mathrm{V}-\mathrm{Cl}$ distance is $2.3308(8) \AA$, and the $\mathrm{V}=\mathrm{O}$ double bond lengths are 1.6124(18) and 1.6276(18) $\AA$. These lengths are in the same range as in the other dioxidovanadates $(\mathrm{V})$, but slightly shorter as in octahedral bis(picolinato)dioxovanadate(V) complex. ${ }^{37}$

Crystal structure of $\mathbf{3}$ is stabilized by hydrogen bonds, $\pi \cdots \pi$ stacking interactions and weak $\mathrm{C}-\mathrm{H} \cdots \mathrm{O} / \mathrm{Cl}$ interactions listed in Table 6. Hydrogen bonds are formed between the pairs of a pyridinium cation and a complex vanadate anion. $\mathrm{N} 2-\mathrm{H} 2$ group of the pyridinium cation is hydrogen-bonded to the carboxylate $\mathrm{O} 3$, as well as to the chlorido $\mathrm{Cl} 1$ atom in the same anion. Hydrogen-bonded pairs are connected into infinite chains parallel to the $b$ axis (Fig. 6) due to $\pi \cdots \pi$ stacking interactions between picolinato (ring centroid $C g 2$ ) and pyridinium rings or between two adjacent pyridinium rings (ring centroid $\mathrm{Cg} 3$ ) with the centroid-to-centroid distances 3.5886(17) and 4.008(2) ̊, respectively. Further stabilization is enabled by weak hydrogen interactions between pyridinium $\mathrm{C}-\mathrm{H}$ and $\mathrm{O} 1, \mathrm{O} 4$ and $\mathrm{Cl} 1$ atoms spreading in all three dimensions (Fig. 7).

Table 6. Hydrogen bonds for $3\left[\AA\right.$ and $\left.{ }^{\circ}\right]$

\begin{tabular}{llllll}
\hline $\mathbf{D}-\mathbf{H} \cdots \mathbf{A}$ & $\mathbf{d}(\mathbf{D}-\mathbf{H})$ & $\mathbf{d}(\mathbf{H} \cdots \mathbf{A})$ & $\mathbf{d}(\mathbf{D} \cdots \mathbf{A})$ & $<(\mathbf{D H A})$ & $\begin{array}{l}\text { Symmetry transformation } \\
\text { for acceptors }\end{array}$ \\
\hline $\mathrm{N} 2-\mathrm{H} 2 \cdots \mathrm{O} 3$ & 0.86 & 2.07 & $2.872(3)$ & 154 & $x, y, z$ \\
$\mathrm{~N} 2-\mathrm{H} 2 \cdots \mathrm{Cl1}$ & 0.86 & 2.72 & $3.357(2)$ & 132 & $x, y, z$ \\
& & & & $x,-y+1 / 2, z-1 / 2$ \\
$\mathrm{C} 7-\mathrm{H} 7 \cdots \mathrm{O} 4$ & 0.93 & 2.55 & $3.347(3)$ & 144 & $-x+1, y-1 / 2,-z+1 / 2$ \\
$\mathrm{C} 8-\mathrm{H} 8 \cdots \mathrm{Cl} 1$ & 0.93 & 2.70 & $3.620(4)$ & 171 & $-x+1,-y,-z+1$ \\
$\mathrm{C} 9-\mathrm{H} 9 \cdots \mathrm{O} 1$ & 0.93 & 2.60 & $3.357(4)$ & 139 & $x+1,-y+1 / 2, z+1 / 2$ \\
$\mathrm{C} 10-\mathrm{H} 10 \cdots \mathrm{O} 1$ & 0.93 & 2.42 & $3.193(3)$ & 141 & $x, y, z$ \\
$\mathrm{C} 11-\mathrm{H} 11 \cdots \mathrm{O} 4$ & 0.93 & 2.40 & $3.222(4)$ & 148 & \\
\hline
\end{tabular}




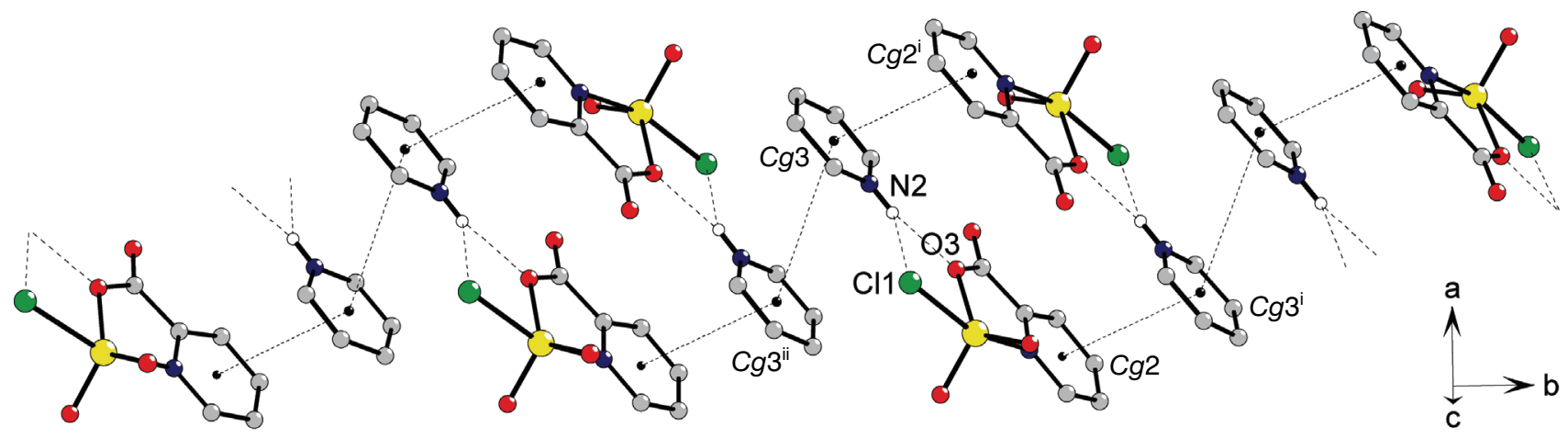

Figure 6. Twisted infinite chains formed by the combination of hydrogen bonds and $\pi-\pi$ stacking interactions in $\mathbf{3}$ forming infinite chain along $b$ axis. Dashed lines indicate hydrogen bonds, and dotted lines indicate centroid-to-centroid distances (symmetry codes: (i) $-x+1,-y+1,-z+1$; (ii) $-x+1,-y,-z+1)$.

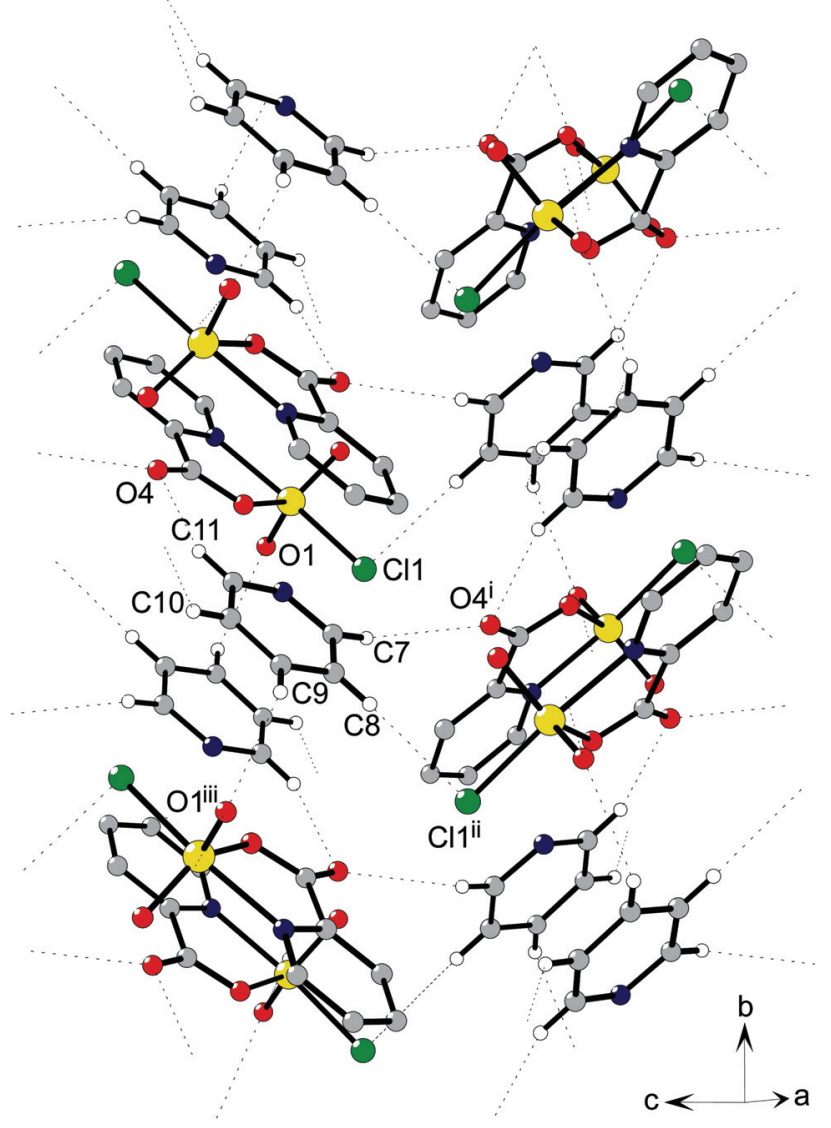

Figure 7. 3D network formed by weak hydrogen bonds in 3. Dashed lines indicate weak $\mathrm{C}-\mathrm{H} \cdots \mathrm{O}$ interactions (symmetry codes: (i) $x,-y+1 / 2, z-1 / 2$; (ii) $-x+1, y-1 / 2,-z+1 / 2$; (iii) $-x+1,-y,-z+1$ ).

\section{Conclusion}

Three vanadium compounds with $\beta$-diketonato or picolinato ligands were prepared and structurally characterized. Compound $\left[\mathrm{VO}(\mathrm{tfpb})_{2}\right]_{\infty}$ (1) represents the first X-ray structure of an oxidovanadium(IV) $\beta$-diketonate with infinite chain formed by the $\mathrm{V}=\mathrm{O} \cdots \mathrm{V}=\mathrm{O}$ interactions. The fluorinated $\beta$-diketonato ligand tfpb enhances the acid character of the vanadium atom and the additional interaction with the adjacent oxidovanadium(IV) group occurs. Compound [VO(acac)(2-pyridone)] (2) has an octahedral structure with the 2-pyridone ligand in trans position to $\mathrm{VO}^{2+}$ group. Even though the carbonyl oxygen of the 2-pyridone ligand is coordinated to the vanadium center, it can still act as a hydrogen bond acceptor facilitating the formation of centrosymmetric hydrogen-bonded dimers via $\mathrm{N}-\mathrm{H} \cdots \mathrm{O}$ interactions with the adjacent molecule. In compound $\mathrm{Hpy}\left[\mathrm{VO}_{2}(\mathrm{pic}) \mathrm{Cl}\right](\mathbf{3})$ the metal center is pentacoordinated with one picolinato and one chlorido ligand coordinated to the dioxidovanadium $(\mathrm{V})$ moiety, and the $\mathrm{Hpy}^{+}$cation is hydrogen bonded to the complex anion. The crystal structure is stabilized by $\pi \cdots \pi$ and $\mathrm{C}-\mathrm{H} \cdots \mathrm{O}$ interactions. This study provides an insight on the influence of different types of ligands on the molecular structure and crystal architecture. Such cases are valuable examples that can help to understand the covalent and non-covalent factors governing the supramolecular aggregation important for crystal engineering and crystal structure prediction.

\section{Supplementary Material}

CCDC 1024846-1024849 (1a-3) contain the supplementary crystallographic data for this paper. These data can be obtained free of charge from The Cambridge Crystallographic Data Centre via www.ccdc.cam.ac.uk/data_request/cif.

\section{Acknowledgment}

The authors thank the Ministry of Education, Science and Sport of the Republic of Slovenia and the Slovenian Research Agency for financial support (P1-02300175) as well as the EN-FIST Centre of Excellence, Trg Osvobodilne fronte 13, 1000 Ljubljana, Slovenia for use of the Supernova diffractometer. 


\section{References}

1. (a) D. Rehder, Future Med. Chem. 2012, 4, 1823-1837; http://dx.doi.org/10.4155/fmc.12.103

(b) H. Sakurai, Y. Yoshikawa, H. Yasui, Chem. Soc. Rev. 2008, 37, 2383-2392; http://dx.doi.org/10.1039/b710347f

(c) G. R. Willsky, L.-H. Chi, M. Godzala III, P. J. Kostyniak, J. J. Smee, A. M. Trujillo, J. A. Alfano, W. Ding, Z. Hu, D. C. Crans, Coord. Chem. Rev. 2011, 255, 2258-2269;

http://dx.doi.org/10.1016/j.ccr.2011.06.015

(d) D. C. Crans, J. J. Smee, E. Gaidamauskas, L. Yang, Chem. Rev. 2004, 104, 849-902.

http://dx.doi.org/10.1021/cr020607t

2. (a) L. G. Naso, M. Valcarcel, M. Roura-Ferrer, D. Kortazar, C. Salado, L. Lezama, T. Rojo, A. C. González-Baró, P. A. M. Williams, E. G. Ferrer, J. Inorg. Biochem. 2014, 135, 86-99; http://dx.doi.org/10.1016/j.jinorgbio.2014.02.013

(b) I. E. Leon, V. Porro, A. L. Di Virgilio, L. G. Naso, P. A. M. Williams, M. Bollati-Fogolín, S. B. Etcheverry, J. Biol. Inorg. Chem. 2014, 19, 59-74;

http://dx.doi.org/10.1007/s00775-013-1061-x

(c) I. E. Leon, A. L. Di Virgilio, V. Porro, C. I. Muglia, L. G. Naso, P. A. M. Williams, M. Bollati-Fogolin, S. B. Etcheverry, Dalton Trans. 2013, 42, 11868-11880.

http://dx.doi.org/10.1039/c3dt50524c

3. (a) S. Sgarbossa, E. Diana, D. Marabello, A. Deagostino, S. Cadamuro, A. Barge, E. Laurenti, M. Gallicchio, V. Boscaro, E. Ghibaudi, J. Inorg. Biochem. 2013, 128, 26-37; http://dx.doi.org/10.1016/j.jinorgbio.2013.07.015 (b) Z. Gao, C. Zhang, S. Yu, X. Yang, K. Wang, J. Biol. Inorg. Chem. 2011, 16, 789-798; http://dx.doi.org/10.1007/s00775-011-0780-0 (c) J. Vinklárek, T. Dìdourková, J. Honzíček, A. Rùžička, J. Inorg. Biochem. 2010, 104, 936-943; http://dx.doi.org/10.1016/j.jinorgbio.2010.04.012 (d) J.-Z. Lu, H.-W. Guo, X.-D. Zeng, Y.-L. Zhang, P. Zhao, J. Jiang, L.-Q. Zang, J. Inorg. Biochem. 2012, 112, 39-48. http://dx.doi.org/10.1016/j.jinorgbio.2012.02.034

4. D. Gambino, Coord. Chem. Rev. 2011, 255, 2193-2203. http://dx.doi.org/10.1016/j.ccr.2010.12.028

5. (a) T. Koleša-Dobravc, E. Lodyga-Chruscinska, M. Symonowicz, D. Sanna, A. Meden, F. Perdih, E. Garribba, Inorg. Chem. 2014, 53, 7960-7976; (b) D. Sanna, M. Serra, G. Micera, E. Garribba, Inorg. Chem. 2014, 53, 1449-1464; http://dx.doi.org/10.1021/ic402366x

(c) D. Sanna, G. Micera, E. Garribba, Inorg. Chem. 2013, 52, 11975-11985; http://dx.doi.org/10.1021/ic401716x (d) S. Mehtab, G. Gonçalves, S. Roy, A. I.Tomaz, T. SantosSilva, M. F. A. Santos, M. J. Romão, T. Jakusch, T. Kiss, J. Costa Pessoa, J. Inorg. Biochem. 2013, 121, 187-195. http://dx.doi.org/10.1016/j.jinorgbio.2012.12.020

6. (a) A. M. Kirillov, G. B. Shul'pin, Coord. Chem. Rev. 2013, 257, 732-754; http://dx.doi.org/10.1016/j.ccr.2012.09.012 (b) J. A. L. da Silva, J. J. R. Fraústo da Silva, A. J. L. Pombeiro, Coord. Chem. Rev. 2011, 255, 2232-2248; http://dx.doi.org/10.1016/j.ccr.2011.05.009 (c) K.-H. Yang, Acta Chim. Slov. 2014, 61, 629-636.

7. A. Ohta, Y. Yamamoto, H. Kamihata, Y. H. Lee, F. Ichikawa, K. Ohta, Y. Abe, N. Hoshino, M. Kojima, S. Hayami, Inorg. Chem. Commun. 2012, 16, 89-91.

http://dx.doi.org/10.1016/j.inoche.2011.12.001

8. (a) D. Barreca, L. Armelao, F. Caccavale, V. Di Noto, A. Gregori, G. A. Rizzi, E. Tondello. Chem. Mater. 2000, 12, 98-103; http://dx.doi.org/10.1021/cm991095a

(b) D. Barreca, L. E. Depero, E. Franzato, G. A. Rizzi, L. Sangaletti, E. Tondello, U. Vettori, J. Electrochem. Soc. 1999, 146, 551-558. http://dx.doi.org/10.1149/1.1391642

9. (a) M. Riou-Cavellec, M. Sanselme, G. Férey, J. Mater. Chem. 2000, 10, 745-748;

http://dx.doi.org/10.1039/a909870d

(b) K. Barthelet, J. Marrot, D. Riou, G. Férey, Angew. Chem., Int. Ed. 2002, 41, 281-284. http://dx.doi.org/10. 1002/1521-3773(20020118)41:2<281::AID-ANIE281>3. $0 . \mathrm{CO} ; 2-\mathrm{Y}$

10. (a) P. Kanoo, A. C. Ghosh, T. K. Maji, Inorg. Chem. 2011, 50, 5145-5152; http://dx.doi.org/10.1021/ic200463k

(b) X. Wang, J. Eckert, L. Liu, A. J. Jacobson, Inorg. Chem. 2011, 50, 2028-2036; http://dx.doi.org/10.1021/ic1025087

(c) A. Phan, A. U. Czaja, F. Gándara, C. B. Knobler, O. M. Yaghi, Inorg. Chem. 2011, 50, 7388-7390;

http://dx.doi.org/10.1021/ic201396m

(d) I. Djerdj, J. Popović, J. Stare, G. Ambrožič, S. D. Škapin, B. Kozlevčar, D. Pajić, Z. Jagličić, Z. C. Orel, J. Mater. Chem. 2012, 22, 10255-10265; (e) I. Djerdj, S. D. Škapin, M. čeh, Z. Jagličić, D. Pajić, B. Kozlevčar, B. Orel, Z. C. Orel, Dalton Trans. 2012, 41, 581-589; (f) Y.-Y. Liu, S. Couck, M. Vandichel, M. Grzywa, K. Leus, S. Biswas, D. Volkmer, J. Gascon, F. Kapteijn, J. F. M. Denayer, M. Waroquier, V. Van Speybroeck, P. Van Der Voort, Inorg. Chem. 2013, 52, 113-120. http://dx.doi.org/10.1021/ic301338a

11. (a) G. R. Desiraju, Angew. Chem. Int. Ed. 2007, 46, 83428356; http://dx.doi.org/10.1002/anie.200700534

(b) L. Brammer, Chem. Soc. Rev. 2004, 33, 476-489.

http://dx.doi.org/10.1039/b313412c

12. (a) F. Perdih, Monatsh. Chem. 2012, 143, 1011-1017; http://dx.doi.org/10.1007/s00706-012-0760-2

(b) S. Shit, R. Sankolli, T. N. Guru Row, Acta Chim. Slov. 2014, 61, 59-66; (c) B. Ardan, Y. Slyvka, E. Goreshnik, M. Mys'kiv, Acta Chim. Slov. 2013, 60, 484-490;

(d) F. Perdih, J. Coord. Chem. 2012, 65, 1580-1591; http://dx.doi.org/10.1080/00958972.2012.676168

(e) M. A. Sharif, G. R. Najafi, Acta Chim. Slov. 2013, 60, 138-143; (f) S. Corti, W. T. Pennington, D. D. DesMarteau, Acta Chim. Slov. 2013, 60, 556-560; (g) R. Vafazadeh, M. Alinaghi, A. C. Willis, A. Benvidi, Acta Chim. Slov. 2014, 61, 121-125; (h) F. Perdih, Acta Cryst. C 2012, 68, m64-m68; (i) L. Saghatforoush, H. A. Rudbari, F. Nicolò, P. Asgari, F. Chalabian, M. Hasanzadeh, V. Panahiazar, Acta Chim. Slov. 2013, 60, 300-309.

13. (a) F. Perdih, Struct. Chem. 2014, 25, 809-819; http://dx.doi.org/10.1007/s11224-013-0344-8

(b) F. Marandi, S. Teimouri, H.-K. Fun, Acta Chim. Slov. 
2013, 60, 328-334.

14. C. Glidewell, in: J. D. Woollins (Ed.): Inorganic Experiments Wiley-VCH, Weinheim, Germany, 1994, pp. 149-151.

15. CrysAlisPRO, Agilent Technologies, Yarnton, England.

16. Z. Otwinowski, W. Minor, Methods Enzymol. 1997, 276, 307-326. http://dx.doi.org/10.1016/S0076-6879(97)76066-X

17. G. M. Sheldrick, Acta Cryst. 2008, A64, 112-122. http://dx.doi.org/10.1107/S0108767307043930

18. A. Altomare, M. C. Burla, M. Camalli, G. Cascarano, C. Giacovazzo, A. Guagliardi, A. G. G. Moliterni, G. Polidori, R. Spagna, J. Appl. Cryst. 1999, 32, 115-119. http://dx.doi.org/10.1107/S0021889898007717

19. M. C. Burla, R. Caliandro, M. Camalli, B. Carrozzini, G. L. Cascarano, L. De Caro, C. Giacovazzo, G. Polidori, R. Spagna, J. Appl. Cryst. 2005, 38, 381-388. http://dx.doi.org/10.1107/S002188980403225X

20. (a) S. Venkataraman, B. Varghese, B. K. Sadashiva, S. Subramanian, Mol. Cryst. Liq. Cryst. 2001, 357, 199-219; http://dx.doi.org/10.1080/10587250108028254

(b) E. Shuter, S. J. Rettig, C. Orvig, Acta Cryst. C 1995, 51, 12-14; http://dx.doi.org/10.1107/S0108270194010462

(c) M. Hoshino, A. Sekine, H. Uekusa, Y. Ohashi, Chem. Lett. 2005, 34, 1228-1229;

http://dx.doi.org/10.1246/cl.2005.1228

(d) K. S. Dichmann, G. Hamer, S. C. Nyburg, W. F. Reynolds, J. Chem. Soc. D 1970, 1295-1296;

http://dx.doi.org/10.1039/c29700001295

(e) U. K. Urs, K. C. Anitha, K. Lakshmi Raghunathan, S. A. Shivashankar, W. T. Robinson, T. N. Guru Row, Acta Cryst. E 2001, 57, m242-m243;

http://dx.doi.org/10.1107/S1600536801007760

(f) M. A. K. Ahmed, H. Fjellvag, A. Kjekshus, B. Klewe, Z. Anorg. Allg. Chem. 2004, 630, 2311-2318;

http://dx.doi.org/10.1002/zaac.200400369

(g) S. S. Amin, K. Cryer, B. Zhang, S. K. Dutta, S. S. Eaton, O. P. Anderson, S. M. Miller, B. A. Reul, S. M. Brichard, D. C. Crans, Inorg. Chem. 2000, 39, 406-416; http://dx.doi.org/10.1021/ic9905897

(h) U. Schilde, W. Bansse, E. Ludwig, E. Uhlemann, Z. Kristallogr. 1995, 210, 627-628.

http://dx.doi.org/10.1524/zkri.1995.210.8.627

21. (a) H. Adams, N. A. Bailey, D. E. Fenton, M. S. Leal Gonzalez, C. A. Phillips, J. Chem. Soc., Dalton Trans. 1983 , 371-379; http://dx.doi.org/10.1039/dt9830000371

(b) P. Hon, R. L. Belford, C. E. Pfluger, J. Chem. Phys. 1965, 43, 3111-3115. http://dx.doi.org/10.1063/1.1697284

22. D. I. Arnold, F. A. Cotton, J. H. Matonic, C. A. Murillo, Chem. Commun. 1996, 2113-2114.

http://dx.doi.org/10.1039/cc9960002113

23. (a) A. Sarkar, S, Pal, Eur. J. Inorg. Chem. 2009, 5391-5398; http://dx.doi.org/10.1002/ejic.200900680

(b) S. Meicheng, W. Lifeng, Z. Zeying, Acta Chim. Sinica 1983, 41, 985-992; (c) S. Meicheng, W. Lifeng, T. Youqi, Chin. Sci. Bull. 1984, 29, 759-764; (d) R. M. S. da Silva, C. C. Spiazzi, R. Bortolotto, R. A. Burrow, Acta Cryst. E 2007, 63, m2422; http://dx.doi.org/10.1107/S1600536807039323 (e) L. Chen, F.-L. Jiang, W.-P. Su, C.-Y. Yue, D.-Q. Yuan, M.-C. Hong, Inorg. Chim. Acta 2009, 362, 407-413; http://dx.doi.org/10.1016/j.ica.2008.04.026

(f) H. Chen, Y. Si, C. Chen, Q. Liu, Acta Cryst. E 2008, 64, m159; http://dx.doi.org/10.1107/S1600536807065439

(g) A. M. B. Bastos, J. G. da Silva, P. I. da S. Maia, V. M. Deflon, A. Batista, A. V. M. Ferreira, L. M. Botion, E. Niquet, H. Beraldo, Polyhedron 2008, 27, 1787-1794;

http://dx.doi.org/10.1016/j.poly.2008.02.014

(h) C. Pretorius, J. A. Venter, A. Roodt, Acta Cryst. E 2012, 68, m1442. http://dx.doi.org/10.1107/S1600536812044686

24. (a) V. Stilinović, D.-K. Bučar, I. Halasz, E. Meštrović, New J. Chem. 2013, 37, 619-623;

http://dx.doi.org/10.1039/C2NJ40780A

(b) T. Ishida, S. Mitsubori, T. Nogami, N. Takeda, M. Ishikawa, H. Iwamura, Inorg. Chem. 2001, 40, 7059-7064;

http://dx.doi.org/10.1021/ic010730n

(c) Z. C. Kadirova, D. S. Rahmonova, S. A. Talipov, J. M. Ashurov, N. A. Parpiev, Acta Cryst. E 2009, 65, m819; http://dx.doi.org/10.1107/S1600536809023113

(d) E. Mestrović, D.-K. Bučar, I. Halasz, V. Stilinović, Acta Cryst. E 2004, 60, m1920-m1922.

25. I. Cvrtila, V. Stilinović, B. Kaitner, Struct. Chem. 2012, 23, 587-594. http://dx.doi.org/10.1007/s11224-011-9905-x

26. (a) M. Tsuchimoto, G. Hoshina, N. Yoshioka, H. Inoue, K. Nakajima, M. Kamishima, M. Kojima, S. Ohba, J. Solid State Chem. 2000, 153, 9-15;

http://dx.doi.org/10.1006/jssc.2000.8710

(b) G. Grivani, S. Delkhosh, K. Fejfarová, M. Dušek, A. D. Khalaji, Inorg. Chem. Commun. 2013, 27, 82-87. http://dx.doi.org/10.1016/j.inoche.2012.10.029

27. (a) N. Matsuoka, H. Kawamura, N. Yoshioka, Chem. Phys. Lett. 2010, 488, 32-37;

http://dx.doi.org/10.1016/j.cplett.2010.01.057

(b) K. Nakajima, M. Kojima, S. Azuma, R. Kasahara, M. Tsuchimoto, Y. Kubozono, H. Maeda, S. Kashino, S. Ohba, Y. Yoshikawa, J. Fujita, Bull. Chem. Soc. Jpn. 1996, 69, 3207-3216; http://dx.doi.org/10.1246/bcsj.69.3207

(c) S. A. Fairhurst, D. L. Hughes, U. Kleinkes, G. J. Leigh, J. R. Sanders, J. Weisner, J. Chem. Soc., Dalton Trans. 1995, 321-326. http://dx.doi.org/10.1039/dt9950000321

28. D. J. Bray, J. K. Clegg, L. F. Lindoy, D. Schilter, Adv. Inorg. Chem. 2007, 59, 1-37.

29. For some examples see: (a) W. Plass, Angew. Chem., Int. Ed. Engl. 1996, 35, 627-631;

http://dx.doi.org/10.1002/anie.199606271

(b) C. E. Schulz, H. Song, Y. J. Lee, J. U. Mondal, K. Mohanrao, C. A. Reed, F. A. Walker, W. R. Scheidt, J. Am. Chem. Soc. 1994, 116, 7196-7203;

http://dx.doi.org/10.1021/ja00095a023

(c) D. Riou, G. Férey, J. Mater. Chem. 1998, 8, 2733-2735; http://dx.doi.org/10.1039/a802711k

(d) W. Kläui, S. Schäfer, W. Peters, H. Wunderlich, Z. Anorg. Allg. Chem. 2006, 632, 2447-2452; http://dx.doi.org/10.1002/zaac.200600211

(e) S. K. Hanson, R. T. Baker, J. C. Gordon, B. L. Scott, D. 
L. Thorn, Inorg. Chem, 2010, 49, 5611-5618; http://dx.doi.org/10.1021/ic100528n

(f) C. Djordjevic, M. Lee, E. Sinn, Inorg. Chem. 1989, 28, 719-723; http://dx.doi.org/10.1021/ic00303a022

(g) V. Zerbib, F. Robert, P. Gouzerh, J. Chem. Soc., Chem. Commun. 1994, 2179-2180.

http://dx.doi.org/10.1039/c39940002179

30. T. Koleša-Dobravc, A. Meden, F. Perdih, Monatsh. Chem. 2014, 145, 1263-1275.

http://dx.doi.org/10.1007/s00706-014-1215-8

31. (a) H. Mimoun, L. Saussine, E. Daire, M. Postel, J. Fischer, R. Weiss, J. Am. Chem. Soc. 1983, 105, 3101-3110; http://dx.doi.org/10.1021/ja00348a025

(b) G. Süss-Fink, L. G. Cuervo, B. Therrien, H. StoeckliEvans, G. B. Shul'pin, Inorg. Chim. Acta 2004, 357, 475-484; http://dx.doi.org/10.1016/j.ica.2003.05.005

(c) L. E. Khoon, T. S. Guan, B. M. Yamin, Acta Cryst. E 2006, 62, m207-m209. (d) N. Smrečki, B.-M. Kukovec, Z. Popović, Monatsh. Chem. 2012, 143, 1471-1477.
32. M. Motevalli, D. Shah, S. A. A. Shah, A. C. Sullivan, Polyhedron 1996, 15, 2387-2395. http://dx.doi.org/10.1016/0277-5387(95)00509-9

33. M. F. Davis, M. Jura, A. Leung, W. Levason, B. Littlefield, G. Reid, M. Webster, Dalton Trans. 2008, 6265-6273. http://dx.doi.org/10.1039/b811422f

34. D. Fenske, A.-F. Shihada, H. Schwab, K. Dehnicke, Z. Anorg. Allg. Chem. 1980, 471, 140-146. http://dx.doi.org/10.1002/zaac.19804710116

35. A. W. Addison, T. N. Rao, J. Reedijk, J. van Rijn, G. C. Verschoor, J. Chem. Soc. Dalton Trans. 1984, 1349-1356. http://dx.doi.org/10.1039/dt9840001349

36. S. Wöckel, J. Gałezowska, S. Dechert, W. Meyer-Klaucke, E. Nordlander, F. Meyer, Eur. J. Inorg. Chem. 2012, 47284738. http://dx.doi.org/10.1002/ejic.201200269

37. M. Melchior, K. H. Thompson, J. M. Jong, S. J. Rettig, E. Shuter, V. G. Yuen, Y. Zhou, J. H. McNeill, C. Orvig, Inorg. Chem. 1999, 38, 2288-2293.

http://dx.doi.org/10.1021/ic981231y

\section{Povzetek}

Pripravili in strukturno okarakterizirali smo tri vanadijeve spojine $\mathrm{z} \beta$-diketonato in picolinato ligandi. V spojinah $\left[\mathrm{VO}(\mathrm{tfpb})_{2}\right]_{\infty}(\mathbf{1})\left(\mathrm{tfpb}=4,4,4\right.$-trifluoro-1-fenilbutan-1,3-dionat) in $\left[\mathrm{VO}(\mathrm{acac})_{2}\right.$ (2-piridon)] (2) je koordinacija vanadijevega atoma oktaedrična, v spojini $\mathrm{Hpy}\left[\mathrm{VO}_{2}(\mathrm{pic}) \mathrm{Cl}\right](3)$ je centralni atom pentakoordiniran. Rentgenska strukturna analiza razkriva tvorbo neskončne verige preko $\mathrm{V}=\mathrm{O} \cdots \mathrm{V}=\mathrm{O}$ vezi v $\mathbf{1}$, medtem ko sta $\mathbf{2}$ in $\mathbf{3}$ enojedrni spojini. V 2 se preko $\mathrm{N}-\mathrm{H} \cdots \mathrm{O}$ vezi s pomočjo koordiniranega 2-piridona tvorijo centrosimetrični dimeri. $\mathrm{V} \mathbf{3}$ je $\mathrm{Hpy}^{+}$kation preko vodikovih vezi vezan na kompleksni anion, kristalna struktura pa je dodatno stabilizirana s $\pi \cdots \pi$ in $\mathrm{C}-\mathrm{H} \cdots \mathrm{O}$ interakcijami. 